\title{
Literatura i religia - stare bolączki, nowe wyzwania (uwagi wstępne)
}

\section{Literature and Religion: Old Worries, New Challenges (Preliminary Remarks)}

Po latach dominacji tak zwanej tezy sekularyzacyjnej, która kazała utożsamiać modernizację z zanikaniem religii, w ostatnich latach nastąpił odwrót od tego upraszczającego schematu. Badania wielu filozofów i socjologów religii, których ukoronowaniem były publikacja $A$ Secular Age Charlesa Taylora, a także głośne wystąpienie Jürgena Habermasa z 2001 roku, przypieczętowały tę zmianę. Transformacje te znalazły swe odzwierciedlenie w literaturoznawstwie na Zachodzie, gdzie zdobył sobie uznanie nurt określany jako badania postsekularne. Czy jednak w polskim literaturoznawstwie nastąpił jakiś przełom? Z jednej strony rodzima humanistyka stosunkowo późno skonfrontowała się z falą sekularyzacji, gdyż narzucany odgórnie materializm marksistowski nie był tym, czym pooświeceniowy ateizm funkcjonujący w warunkach demokracji liberalnej. Z drugiej strony to właśnie nad Wisłą rozwijał się zaskakująco nowoczesny nurt badań nad literaturą i religią, którego najbardziej rozpoznawalnymi koryfeuszami byli Stefan Sawicki i Jan Błoński.

Dziś jednak przed badaniami tymi stoją nowe wyzwania. Jakie one są? Jak naświetlać obecnie związki literatury i religii? Jak w praktyce interpretacyjnej zdać sprawę z doświadczenia pluralizmu światopoglądowego, który wpływa na reguły odbioru? Jak interpretować utwory religijnie „podejrzane”? To tylko kilka z pytań, które stawiamy w tym numerze „Kontekstów Kultury”.

$\mathrm{Z}$ wielką przyjemnością prezentujemy rozmowę z Davidem Jasperem (The Weakening of Theology by Literature Is Not a Bad Thing), jednym z najwybitniejszych badaczy związków literatury i religii, który założył brytyjskie pismo „Literature and Theology” i opublikował wiele kanonicznych już dla tej problematyki książek. Z jego wypowiedzi płynie wniosek, że takie pograniczne badania muszą opierać się na teologii, zarazem jednak wykorzystywana w nich teologia powinna godzić się na „osłabianie” przez żywioł literatury. 
Do spostrzeżeń Jaspera nawiązuje Jean Ward („Zobaczyć świat w ziarenku piasku". Przyczynek do refleksji nad "literatura a religia" z perspektywy pogranicz$n e j)$, która dzieli się swymi doświadczeniami badaczki zawieszonej między kulturą brytyjską i polską oraz pokazuje jeszcze inny wymiar „pograniczności” tej pogranicznej dyscypliny. W obrębie literatury języka angielskiego porusza się także Małgorzata Grzegorzewska (Baranek czy tygrys? Nie-ludzkie oblicza Boga w poezji T.S. Eliota i R.S. Thomasa). W swym pięknym eseju tropi sensy chrystologicznej symboliki baranka i tygrysa u Williama Blake'a, T.S. Eliota i R.S. Thomasa. Ważnym uzupełnieniem tych trzech głosów odkrywających nowe perspektywy badań nad literaturą i religią są propozycje Piotra Bogaleckiego (,Z kronik wspótczesnej mistyki”- Adam Zagajewski i Nowa Fala [opowieść postsekularna]), który przygląda się twórczości Adama Zagajewskiego z perspektywy postsekularnej.

Nieocenionym dodatkiem do tych rozważań są teksty zorientowane bardziej historycznoliteracko. Joanna Rzepa (Reinventing Saint Francis: Józef Wittlin, Anti-Semitism and the Idea of Modern Sainthood) bada związki Józefa Wittlina z katolickim modernizmem i pokazuje dylematy pisarza, który uporczywie powracał do pytania: „jak osiagnąć chrześcijański ideał świętości w stuleciu, które zostało naznaczone narastającymi niepokojami politycznymi, masową przemocą (...) i powszechnym antysemityzmem, prowadzącym do ludobójstwa milionów europejskich Żydów"? Marek Tomaszewski (Georges Bernanos, czyli chrześcijaństwo bez taryfy ulgowej) przypomina sylwetkę Georgesa Bernanosa, niezwykle wpływowego pisarza (zwłaszcza w Polsce XX-lecia międzywojennego), który wyznaczał wzorzec „powieści katolickiej”. Andrzej Tyszczyk (Lament i konsolacja. O dwóch obrazach Boga w tekstach z getta warszawskiego), sięgając do tekstów Kalmana Shapiry i Icchaka Kacenelsona, ukazuje dramatyczny kryzys wiary w obliczu Holocaustu. Przekonuje jednak, że: „»Bóg cierpiący« z kazań rabbiego Shapiry i »okrutne ukrzyżowanie« z poematu Kacenelsona to dramatyczne próby ocalenia Boga wiary w piekle Endlösung". W numerze o literaturze i religii nie mogło zabraknąć osobnego szkicu o poezji Czesława Miłosza, który jest chyba najważniejszym dla pogranicza literatury i religii polskim pisarzem. Anna Szczepan-Wojnarska (,Who Would Be a Prophet”. Prophetic Aspects of Czestaw Mitosz's Poetry) wskazuje na paradoksalny, daleki od romantycznej tradycji wieszcza, profetyczny wymiar twórczości autora.

Mamy nadzieję, że prezentowane tu teksty okażą się inspirujące dla „pograniczników" badających związki literatury i religii. Chcielibyśmy, by służyły pomocą i utwierdzały w przekonaniu, że warto zapuszczać się na te „cudne manowce”.

Eukasz Tischner Redaktor prowadzacy zeszytu 